DOI: $10.17805 /$ trudy.2016.5.8

\title{
ПРОБЛЕМЫ ФОРМИРОВАНИЯ КРЕАТИВНОЙ ЛИЧНОСТИ СОВРЕМЕННОГО СПЕЦИАЛИСТА
}

\author{
Е. М. Акимова \\ (Московский гуманитарный университет)
}

\begin{abstract}
Аннотация: В статье исследуется проблема значимости формирования креативного специалиста для создания в современных условиях эффективной экономики в России, преодоления кризисных процессов в стране, анализируются факторы, способствующие развитию творческого потенциала личности специалиста, а также причины, препятствующие проявлению творческих способностей работника в организациях и на производстве.
\end{abstract}

Ключевые слова: креативная личность; творческий потенциал; самореализация личности; инновационные образовательные технологии; культурная политика; корпоративная культура; развитие креативности

\section{CREATIVE PROFESSIONALS: ISSUES OF PERSONALITY DEVELOPMENT}

\author{
E. M. Akimova \\ (Moscow University for the Humanities)
}

Abstract: The article examines the importance of training creative professionals to make the economy of contemporary Russia efficient and overcome the current crisis. We look at the factors that promote the creative capabilities of a professional, as well as the obstacles to creative work in business and industry.

Keywords: creative personality; creative capabilities; self-actualization; innovative technologies in education; cultural policy; creative development

Эффективность современной развитой экономики определяется прежде всего скоростью создания и внедрения новейших производственных технологий, быстрым внедрением инновационных разработок и ростом наукоемких отраслей. Важнейшим фактором эффективного инновационного развития такой экономики и всех сфер общественной жизни является человек - работник креативный, обладающий могучим творческим потенциалом. В настоящее время 40\% ВВП развитых стран создаются за 
счет интенсивного «включения интеллекта и творческих способностей в исполнение рутинных операций», что говорит о первостепенном значении творческого потенциала работника для всестороннего обновления общества и его быстрого развития (Флорида, 2005: 28).

Специалисты в области рекламных компаний утверждают, что использование творческого потенциала персонала в коммерческой организации может стать неисчерпаемым источником новых идей и новых конкурентных преимуществ. Является ли креативность личности залогом обеспечения инновационного развития России, открытия неограниченных возможностей для роста производительности труда, повышения его качества, создания и внедрения в практику принципиально новых технологий, техники, совершения научных открытий в нашей стране? В Концепции социально-экономического развития Российской Федерации на период до 2020 г. указывается: «Формирование инновационной экономики означает превращение интеллекта, творческого потенциала человека в ведущий фактор экономического роста и национальной конкурентоспособности» (Распоряжение Правительства ..., Электр. ресурс).

Для того, чтобы понять, почему и насколько важна креативность специалиста и как ее сформировать, целесообразно определить прежде всего отличительные черты креативной личности. В науке существуют разные подходы к данному вопросу. Э. Фромм считает, что творческий потенциал личности проявляется в способности озадачиваться, концентрироваться, принимать конфликт, в готовности к преобразованиям каждый день. А. Маслоу акцентирует внимание на нацеленности личности на создание нового. Современные исследователи (Д. Пиирто, например) видят проявление креативности в богатом воображении, предвидении, пытливости, интуиции, готовности пойти на риск (Пахтер, 2013).

Креативность, с нашей точки зрения, это комплексная характеристика личности, которая проявляется в ее способности ставить и решать новые задачи, старые задачи разрешать по-новому, в потребности к саморазвитию, самореализации, созданию нового. Творческий потенциал работника - это его компетентность, умение решать проблемы, развитость интеллекта, творческие способности, духовный потенциал, лидерские качества, мотивация.

Огромную роль в развитии творческих способностей, формировании креативной личности специалиста играют инновационные методы обучения, которые

•активизируют мышление, требуют самостоятельно принимать творческие по содержанию, эмоционально окрашенные и мотивационно оправданные решения, развивают партнерские отношения;

• повышают результативность обучения не за счет увеличения объе- 
ма передаваемой информации, а за счет глубины и скорости ее переработки;

- обеспечивают стабильно высокие результаты обучения и воспитания при минимальных усилиях студентов.

Программа деятельностного обучения означает переход от принципа «сядь и прочитай это/посмотри на это» к принципу «встань, пересядь на другое место в команду, сделай это и действительно научись».

Переход к инновационным образовательным технологиям означает реализацию одного из основополагающих принципов современного образования - принципа личностного подхода, позволяет максимально развить творческий потенциал личности, воспитать человека, способного наряду со знаниями, умениями, навыками привнести в дело свой талант, целеустремленность.

Большое значение для формирования креативной личности имеет инсценировка ситуаций. В этом случае участникам предлагается реалистичная ситуация и между ними распределяются конкретные роли. Внимание при этом сосредотачивается не на решении проблемы, а на развитии навыков взаимодействия. Эффективность особенно велика, если ситуация имеет выраженное сходство с реальной жизненной или производственной ситуацией. Важно, что студенты видят реакцию на свои действия, что развивает у них уверенность в себе и является важным условием креативного мышления. Инсценировка ситуаций способствует и развитию навыков межличностного общения, учит их, как действовать в реальных ситуациях.

Наработать навык решения проблем различного рода будущим специалистам помогает ситуационный анализ, который предусматривает письменное описание реальной ситуации или проблемы. Участникам предлагают найти выход и необходимое решение. Достоинства данного инновационного метода состоят в том, что:

- ситуации обычно очень интересны;

- группа активно обсуждает большое число разных решений, так как не существует единственно возможного, ищет новые подходы к разрешению ситуации;

- метод развивает умение студентов эффективно общаться, оценивать различные факторы, влияющие на принятие решения, принимать креативное решение в реальной жизни.

Среди всех методов инновационного обучения наиболее действенным является тренинг. Именно данная форма позволяет глубоко усваивать теоретические знания и одновременно вырабатывать практические навыки рационального профессионального взаимодействия, вырабатывает инновационный подход к работе и жизни. Позитивная коммуника- 
ция, умелый учет и устранение возможных коммуникационных барьеров в ее процессе имеют первостепенное значение для специалиста любого профиля.

Тренинговые занятия позволяют всесторонне изучить особенности деловой коммуникации, сформировать профессиональные навыки по применению эффективных средств общения, преодолению барьеров общения, обучить самостоятельному анализу техники продуктивного взаимодействия в профессиональной деятельности, изучить особенности коммуникационного взаимодействия, присущие тем или иным социальным ролям. Большое значение имеет овладение знаниями и опытом межличностного и служебного делового взаимодействия, умение регулировать возникающее эмоциональное напряжение в его процессе, отработка специальных техник постановки вопросов, малого разговора, активного слушания и др.

Важную роль в развитии коммуникативной компетентности имеют упражнения по самопрезентации, моделирование различных форм вербального общения: публичных выступлений, переговоров, дискуссий, конфликтов в игровой ситуации.

Тренинговые занятия позволяют нарабатывать социальные и жизненные умения, которые являются неотъемлемой составной частью любого социального взаимодействия.

Особенность данного метода состоит в том, что он в случае необходимости дает возможность перепрограммировать поведение и деятельность человека. Подобные навыки необходимы специалисту для успешного взаимодействия с сотрудниками, клиентами.

Основными принципами тренинговых занятий являются активность участников, их исследовательская (творческая) позиция, объективация (осознание) особенностей своего реального поведения, партнерское (субъект-субъектное) общение.

Тренинговые упражнения направлены и на развитие определенных личностных черт, таких как целеустремленность, решительность, стрессоустойчивость, коммуникабельность, высокая работоспособность, уверенность, креативность.

Эти занятия позволяют осознать в себе творческие способности, развивать их дальше, формировать навыки творческого самочувствия. Важную роль играет также осознание и преодоление барьеров креативности, усвоение характеристик креативной среды. Специальные упражнения дают возможность научиться управлять процессом творчества.

Большую роль в развитии творческого потенциала работника играет приобщение его к культуре (художественной, музыкальной, театральной, кино, литературе), что способствует духовному развитию личности, фор- 
мированию у нее потребностей в самосовершенствовании, самоактуализации, стимулирует к поиску и созданию нового, развивает социальную активность. Именно поэтому Президент России В. В. Путин еще в июне 2003 г. на заседании Госсовета в качестве приоритетной задачи культурной политики определил - «обеспечить доступность культуры для граждан» (Стенографический отчет ..., 2003: Электр. ресурс). Однако, проблема состоит в том, что в последние годы в нашей стране наблюдается сокращение уровня культурного потребления.

Социологические и статистические обследования населения выявляют зависимость между уровнем доходов и интенсивностью культурного потребления. Так, в группе населения с минимальным доходом на организацию отдых и культурных мероприятий затраты в семейном бюджете составили в 2010 г. 2, 8\%, а в группе с максимальным доходом - в 2,5 раза больше, $7,1 \%$.

В 2012 г. фактор отсутствия средств, которые можно было бы потратить на посещение театра, покупку книг, дисков и т. д. имел существенное значение для 67,3\% респондентов. Более того, в силу экономических причин для 30\% потенциальных читателей хорошая книга была «не по карману», а для 27,1\% респондентов круг культурных благ был очень ограничен. Такое положение дел привело, неизбежно, к снижению уровня духовной культуры населения, уменьшению культурной активности, что подтверждается социологическими исследованиями 2013 г., проведенные центром РАГС при Президенте Российской Федерации по заказу Министерства культуры РФ. На вопрос, обращенный к молодежи, «Как часто Вы посещаете следующие учреждения культуры?», 59,8\% ответили, что не посещают выставок и вернисажей, 59\% - дворцы и дома культуры, 53,7\% - концертные залы, 46,8\% - театры, 45\% - музеи. Более трети опрошенных не бывают даже в культурно-развлекательных центрах, клубах и дискотеках. И это несмотря на то, что в инфраструктуре городов и сел страны эти учреждения культуры есть и молодежь имеет об этом представление: 91\% - о наличии библиотеки, 77\% - о том, что в городе есть музей, 76\% знают о существовании развлекательного центра.

Снижение уровня духовной культуры населения и культурного уровня в целом существенно влияет на творческую активность работника. Проведенные опросы среди трудоспособного населения Вологодского региона в 2011 г., например, показали, что более $42 \%$ опрошенных «никогда ничего не предпринимали сами, делали только то, чему их научили раньше или что подсказывали другие», то есть не обращались к творчеству; 21\% занимались творчеством только по принуждению со стороны руководства; $25 \%$ прибегали к творчеству в случае практической необходимости, и лишь для 9\% респондентов «творчество - это стиль жизни» (Пономарев, 2014: 
302). Таким образом, решение задачи широкого приобщения населения к культуре и искусству - необходимое условие повышения творческого потенциала работника и напрямую связано с ростом доходов населения, расширением спектра бесплатных услуг в сфере культуры.

Существенное воздействие на формирование и развитие творческого потенциала оказывают нормы корпоративной культуры, которые внедряют в поведение работника креативность (потребность и способность выдвигать необычные идеи, отклоняться от традиционных схем, быстро разрешать проблемные ситуации) (Управление организацией, 2000: 669).

Корпоративная культура поощряет самообучение, саморазвитие, самоактуализацию, создает условия для разработки и внедрения рационализаторских предложений, проявления инициативы, развивая тем самым творческий потенциал специалиста.

Существенной проблемой в создании высокого творческого потенциала в организации является налаживание взаимодействия с творческими работниками, формирование в ней соответствующей корпоративной культуры. Труд одаренных сотрудников является важной составляющей успеха организации, но взаимодействие с ними связано с большими трудностями, поскольку они независимы, амбициозны, умны и выходят за рамки привычных стандартов.

Одаренные люди характеризуются стремлением к исследованию окружающего мира, не терпят ограничений и запретов, умеют анализировать и делать выводы, обладают отличной памятью, умело распоряжаются приобретенными знаниями и умениями, с удовольствием берутся за решение самых сложных задач, предлагая неординарные пути их решения, склонны к постоянному изобретательству и творчеству. Это, с одной стороны. С другой стороны, они предполагают, что все работники такие, как они. На этой почве часто возникают конфликты, появляется некоторое отторжение талантливых людей от основной массы работников. Именно корпоративная культура помогает разрешить эти конфликты, а также устранить причины, препятствующие творчеству работников.

К снижению творческой активности личности ведут следующие факторы: эмоциональные - страх ошибиться, выглядеть смешным, некомпетентным, осуждаемым другими сотрудниками; профессиональные - неопытность, соперничество, категоричные суждения, отсутствие альтернативных вариантов, узкоспециальные знания; особенности восприятия - односторонность мышления, отсутствие необходимого интеллектуального уровня; личностные - чувствительность, лень, самомнение, эгоизм, консерватизм.

Установлено также, что проявлению творческих способностей мешают отсутствие четко определенной цели, подмена целей, страх пораже- 
ния, страх перед успехом, страх перемен, ярко выраженное стремление к безопасности (Управление персоналом ..., 2013: 381).

Главным в формировании необходимых условий для творческих работников является руководитель, его личностные особенности, его стиль руководства. Существует система правил взаимодействия руководства организации с одаренными и талантливыми людьми. Руководителю необходимо быть честным к себе и другим. Талантливые люди чувствительны ко лжи, их психика подвержена влиянию неправды и несправедливости; целесообразно избегать длинных объяснений и нравоучений с талантливыми людьми. Они многое понимают с полуслова. Следует уважать в людях индивидуальность, неповторимость. Не загонять их «в прокрустово ложе» своих представлений.

Важно чаще отмечать у одаренных людей их достоинства. Следует научиться с большой долей терпения воспринимать эмоциональные перепады талантливого человека. Большое значение имеет умение поощрять разногласия в идеях и мнениях; давать возможность творчески настроенным работниками активно участвовать в принятии решений и формировании планов; изменять традиции старшинства, чтобы сотрудники могли продвигаться с любого уровня в полном соответствии с их достоинствами; предоставлять больше свободы своим работникам, чтобы они могли работать с максимальной самостоятельностью; не ограничивать талантливых работников рутинными работами, а развивать их интересы и ставить перед ними новые увлекательные задачи; быть терпимыми к странным идеям. Необходимо делать все, чтобы избежать общественного неодобрения талантливых людей, уменьшить социальные трения и негативную реакцию персонала организации. Такими должны быть правила взаимодействия с одаренными людьми, принятые ценности и нормы, традиции, ритуалы, формы общения между сотрудниками, которые являются неотъемлемой частью корпоративной культуры. Таким образом, очевидно, что важнейшим фактором развития творчества персонала выступает корпоративная культура.

В заключении следует отметить, что формирование креативной личности современного специалиста имеет важнейшее значение для инновационного развития Российского общества, преодоления проявлений развернувшегося мирового кризиса в нашем государстве. Особенно актуально использование для развития творческого потенциала личности инновационных методов обучения, широкого привлечения населения к культуре и духовным ценностям, внедрение в сознание специалиста норм креативного поведения через корпоративную культуру.

Однако, недостаточное использование инновационных методов обучения в вузах, наблюдаемое снижение уровня культурного потребления 
населения, расширение влияния массовой культуры, преобладание авторитарной массовой культуры в настоящее время в стране сдерживают существенно рост творческого потенциала современного специалиста в России.

\section{СПИСОК ЛИТЕРАТУРЫ}

Пахтер, М. (2013) Культура на перепутье: культура и культурные институты в XX веке. М. : Классика-XXI. 321 с.

Пономарёв, Я. А. (2014) Психология творчества. М. : Наука. 357 с.

Распоряжение Правительства РФ от 17.11.2008 N 1662-р (ред. от 08.08.2009) «О Концепции долгосрочного социально-экономического развития Российской Федерации на период до 2020 года» (вместе с «Концепцией долгосрочного социально-экономического развития Российской Федерации на период до 2020 года») [Электронный ресурс] // КонсультантПлюс. URL: http://www.consultant.ru/document/cons_doc_LAW_82134/28c7f 9e359e8af09d7244d8033c66928fa27e527/ (дата обращения: 12.10.2016).

Стенографический отчет о заседании Государственного совета по вопросам развития российской культуры (2003) [Электронный ресурс] // Президент России. Официальный сайт. 16 июня. URL: http://kremlin.ru/ events/president/transcripts/22025 (дата обращения: 12.10.2016).

Столяров, А. М. (2013) Методы активизации творческого мышления. M. 387 c.

Управление организацией (2000) : учебник для вузов / под ред. А. Г. Поршнева, 3. П. Румянцевой, Н. А. Соломатина. 2-е изд., доп. и перераб. М. : ИНФРА-М. 669 с.

Управление персоналом на производстве (2013) : учебное пособие для вузов / Бурносова Н. М., Шаталова,Н. И. М. : ЮНИТИ. 381 с.

Флорида, Р. (2005) Креативный класс: люди, которые меняют будущее. М. : Классика-XXI. 257 с.

Акимова Елена Михайловна - кандидат исторических наук, доцент кафедры социологии Московского гуманитарного университета. Адрес: 111395, Россия, г. Москва, ул. Юности, д. 5, корп. 1. Тел.: +7 (499) 374-60-21. Эл. адрес: e.m.akimova@yandex.ru

Akimova Elena Mikhailovna, Candidate of History, Associate Professor, Department of Sociology, Moscow University for the Humanities. Postal address: 5 Bldg. 1 Yunosti St., 111395 Moscow, Russian Federation. Tel.: +7 (499) 374-60-21. E-mail: e.m.akimova@yandex.ru 